\title{
VOX STUDENTIUM VOX DEI DECALOGUE FOR STUDENTS
}

\section{George N. Chaldakov}

\section{Department of Anatomy and Cell Biology, Faculty of Medicine, Medical University of Varna}

1. He who learns, he will succeed. (Bulgarian proverb)

2. Forward! Science is a sun, / which in our souls shines! ${ }^{*}$ - not only on May 24, the Bulgarian National Day of Cyrillic Alphabet and Culture, but continuously throughout life (CME - Continuing Medical Education; LLP - Laboratory, Library, Pub; also Lifelong Learning Program).

3. Follow didactic cascade: from information to knowledge to way of thinking. Feel the knowledge like you feel your mother tongue. Transmitted to biomedical education, this means transdifferentiation of information about cellular molecules, structures and functions (MSF) into knowledge about the pathogenesis of diseases and their prevention and therapy $(\mathrm{DPT}) .{ }^{* *}$ Remember: there are no departments and clinics within the cell.

4. Learning without thinking is useless. Thinking without learning is dangerous. (Confucius)

5. Imagination is more important than knowledge because knowledge is limited. (Albert Einstein) - see the drawing entitled Stream of Associations.

6. Follow your parents' advice: WHAT DID I ARRIVE HERE FOR? - to study first, then rejoice - the reverse chronology is meaningless.

7. Healthy lifestyle and good education can ensure your quality of life (QoL).

8. Human cognitive potential is a symbiosis of thoughts and emotions. Also, think outside the box.

9. Develop moral reflexes - mutual respect and love for each other, create and enjoy brain-and-heart friend/ship $(B H F)$.

10. Have the courage to cross at least once at a red light on the road of science to make your own green path on it. To achieve your Eureka effect.

${ }^{*}$ From Stoyan Mihaylovski's poem, a traditional song of all Bulgarian schools.

** Being the author of a textbook is a deep responsibility.

Paraphrased from Emily Dickinson (Being a flower is a deep responsibility.)

Principles of Cell Biology (1 ${ }^{\text {st }}$ English edition, to hopefully be released December 2017) provides students and teachers with an accessible approach to state-of-the-science (SoS)-based fundamental concepts of cell biology. The textbook is written in-depth and it is desirable to be read in-depth if the reader wants to get in-depth information and knowledge about cellular MSF and their importance for the understanding of DPT. Principles of Cell Biology is a didactic shift from the traditional focus on details towards an integrative, translational, bench-to-bedside (BtB) view of cell biology. I hope it will be useful for inquisitive students, lecturers, PhDs and MDs, here in Bulgaria as well as globally.

BHF-ly yours,

George N. Chaldakov, MD, PhD, DHC, FIACS

Department of Anatomy and Cell Biology, Medical University, Varna, Bulgaria 


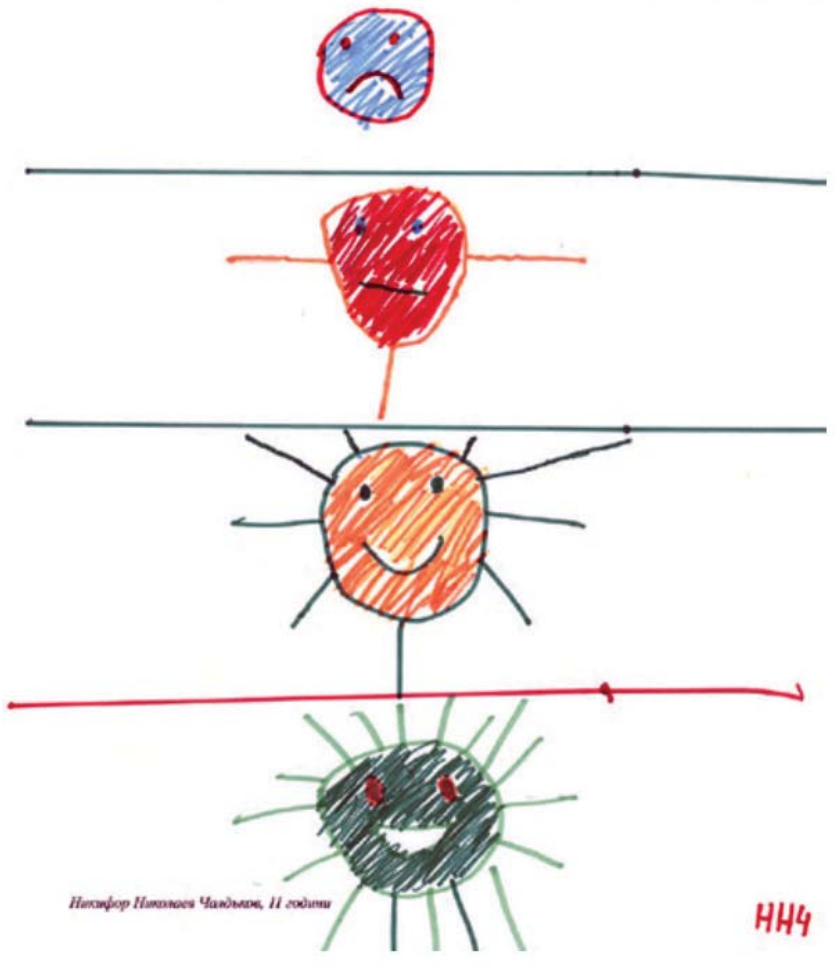

